Marija Đekić ${ }^{1}$

Miloš Nikoliće

Raica Milićević ${ }^{3}$

College of Business Economics and Entrepreneurship,

Belgrade
SCIENTIFIC REVIEW ARTICLE

doi:10.5937/ekonomika1903103D

Received: Jul, 12. 2019.

Accepted: September, 09. 2019.

\title{
CAUSES, MANIFESTATIONS AND REPRESENTATION OF THE SHADOW ECONOMY WITH REFERENCE TO SERBIA
}

\begin{abstract}
Shadow economy is a collection of economic activities which do not contribute to one country's GDP, which the state does not have control over and which are beyond the limits of legality. In this paper, we will show the causes, manifestations, consequences and representation of the shadow economy in Serbia. Likewise, we shall talk about the problem of assessing the shadow economy, about the factors causing it and about the systematization of its advantages and disadvantages. The shadow economy is still a big problem for the domestic economy even though Serbia has decided to fight it with different measures.
\end{abstract}

Key words: shadow economy, tax evasion, economic system regulation, tax policy, the fight against the shadow economy

JEL classification: $\mathrm{H26}$, 017

\section{УЗРОЦИ, ПОЈАВНИ ОБЛИЦИ И ЗАСТУПЉЕНОСТ СИВЕ ЕКОНОМИЈЕ СА ОСВРТОМ НА СРБИЈУ}

\begin{abstract}
Апстракт
Сива економија представља скуп економских послова који не доприносе БДП-у земље, над којима држава нема контролу и који излазе из оквира законитог пословања. У раду ће бити речи о узроцима, појавним облицима, последицама и заступьености сиве економије у Србији. Такође, ће раду бити изложен проблем мерења сиве економије, биће приказани фактори који је изазивају и изврииће се систематизачија юених предности и недостатака. Сива економија и даље представља велики проблем домаће привреде, иако је Србија овом проблему сиве економије одлучила да се супротстави различитим мерама.
\end{abstract}

Кључне речи: сива економија, пореска евазија, регулација привредног система, пореска политика, борба против сиве економије

\footnotetext{
${ }^{1}$ djekic.maja990@gmail.com

${ }^{2}$ milos.nikolic@vspep.edu.rs.

${ }^{3}$ raica.milicevic@gmail.com
} 


\section{Introduction}

The fight against the shadow economy is an ordeal of every country in the world since this phenomenon is present around the globe. The European Commission states that the notion of theshadow economy implies illegitimate (illegal) activities performed in the aim of conducting economic transactions. Surely, participants in economic transactions are trying to do business on the margins of the economic system when they can benefit from it, but that means that the country's budget is left without its incomes on the basis of taxes and contributions which then leads to problems in financing social non-profit activities directly financed from the budget. Illegitimate or semi-legitimate shadow economy mechanisms are manifested in not paying fiscal obligations, such as taxes and contributions, not respecting and/or avoiding to do business in accordance with the regulations which then leads to the emergence of market disturbances and structural changes.

According to OECD, the grey or shadow economy is described as that segment of economy which covers illegal, illegitimate, hidden, informal and other non-registered production activities which cannot be covered by the statistical system of one country (OECD, 2002, pp. 11-15). Adam Smith defined theshadow economy as "a market-based production or provision of services, legal or illegal, performed in such a way to avoid detection in the official estimates of the country's GDP" (Smith, 1994). The shadow economy is most commonly defined as a collection of all non-registered economic activities not contributing to the GDP of one country (Schneider, 2011, pp. 2-3).

From the aspect of legality, the notion of shadow economy refers to all phenomena beyond legal regulative (the so-called informal economy) and contrary to the laws (the socalled illegal economy).

From the aspect of participants acting on their own, within groups or organizations, and who do not declare themselves, who are not registered anywhere and do not pay taxes, we differentiate between three types of economy - undeclared economy, unregistered economy and evasion. Hence, the shadow economy can be observed as a non-regular economy and black economy and in both cases it signifies the striving of market participants to obtain illegal benefits. The presence of the shadow economy causes the existence and expansion of black economy as an illegal form of business activities.

A wide range of the shadow economy always causes disturbances in the allocation of GDP, at both macro and micro levels. At the macro level, the shadow economy causes disturbances in the global allocation of incomes between the economy and the country which reduces budgetary incomes and the level of tax burden placed on the total economy. In trying to place money in the budget, tax authorities will, due to the rise of theshadow economy, compensate tax losses by increasing tax rates. That, on the other hand, burdens the tax-paying population, thus increasing their expenses and reducing competitiveness. Illegal financial transactions can be performed by a narrower circle of citizens having bigger incomes which consequently leads to an income increase at the expense of those with lower incomes. At the micro level, the shadow economy creates great inequalities in the burdening of tax payers by questioning the principle of tax burdening towards the economic power of taxpayers. In that way, shadow economy disables the realization of an adequate tax policy.

According to the volume of the shadow economy, Serbia unfortunately takes an infamous place and is on the top of the list of European countries. Visible manifestations of the shadow economy in Serbia are tax evasion, market distortion, disloyal competition and 
inefficient allocation of resources. Difficult conditions in Serbian economy, such as inflation and sanctions, have led to people opting for the shadow zone out of sheer necessity while simply trying to survive.

\section{Causes, forms and consequences of the shadow economy}

The main factors leading to the existence and expansion of theshadow economy are: doing business in uncertain conditions (war, natural disasters), economic conditions followed by long-term developmental crises, high reduction of production and aggregate offer, decrease in the standard of living followed by an increase in the number of unemployed people, general uncertainty regarding the legal and economic systems, lack of trust in the financial system and fear from inflation due to past experiences, lack of will and a systematic approach in making regulations against the shadow economy, as well as a tolerant attitude of the government, especially in the field of foreign trade. The causes of the shadow economy can be systemized in different ways, and according to how they occurred, they can be observed as: economic (inflation, high tax rates, mild penalties, high profit), psychological (lack of trust in the country, disagreeing with state measures, personal attitude to risk) and opportunitybased (education, work experience). According to Novaković (2015), the primary cause of the growth of the shadow economy in Serbia are neoliberal models of transition, privatization, the degradation of the social country and the erasing of achieved social and economic rights of the employees, dependency on the international community and institutions, low activity and employment rate, i.e. high unemployment rate of the working-age population, low rate of work productivity, weak legal state and the lack or inefficiency of institutions relevant for the functioning of the market economy, restrictive work and social legislations safeguarding employers instead of employees, tax system weaknesses, high level of population poverty, unstable business and people's ethics, i.e. the existence of bribery and corruption.

The participants in theshadow economy can make a decision to perform a certain illegal activity in its shadow forms for the following reasons (Schneider, 2006, p. 5):

1. Avoiding to pay value added taxes, income taxes or other forms of taxes;

2. Avoiding to pay contributions for the social insurance categories;

3. Avoiding to apply the prescribed work standards referring to, for example, the amount of minimum wage, max work hours, work safety standards, etc.

4. Avoiding to harmonize one's business with the prescribed administrative procedures such as, for example, avoiding to deliver or show financial business reports.

The shadow economy appears in different forms and in all areas. The manifestation forms of the shadow economy are reflected in: an illegal import and export; unregistered entry and export of foreign currency; the withdrawal and retention of cash outside the payment channel, the smuggling of goods into the domestic market, the keeping of goods outside of circulation; selling of goods on the black market; tax evasion, the use of work hours for private purposes, unregistered provision of various services, incomplete revenue coverage; illegal construction, unlawful appropriation of common premises in residential buildings, misuse of official, business and public position, usurpation of public goods, etc. 
Table 1: Shadow economy forms in the field of legal and illegal activities

\begin{tabular}{|c|c|c|c|c|}
\hline $\begin{array}{l}\text { Activity } \\
\text { type }\end{array}$ & \multicolumn{2}{|l|}{ Monetary transactions } & \multicolumn{2}{|c|}{ Non-monetary transactions } \\
\hline $\begin{array}{l}\text { Illegal } \\
\text { activities }\end{array}$ & \multicolumn{2}{|c|}{$\begin{array}{l}\text { Trade of stolen goods, production and } \\
\text { circulation of drugs, gambling, trafficking, } \\
\text { smuggling, frauds, etc. }\end{array}$} & \multicolumn{2}{|c|}{$\begin{array}{l}\text { Exchanging (bartering) drugs, stolen and } \\
\text { smuggled goods, production of drugs for } \\
\text { personal use, theft for personal use. }\end{array}$} \\
\hline & Tax evasion & Tax avoidance & Tax evasion & Tax avoidance \\
\hline $\begin{array}{l}\text { Legal } \\
\text { activities }\end{array}$ & $\begin{array}{l}\text { Unregistered incomes } \\
\text { made by self- } \\
\text { employment activities; } \\
\text { wages; incomes; fees; } \\
\text { incomes made in } \\
\text { unregistered business } \\
\text { activities related to legal } \\
\text { services and product } \\
\text { circulation. }\end{array}$ & $\begin{array}{l}\text { Employee } \\
\text { discounts; benefits } \\
\text { which enable } \\
\text { participation in tax } \\
\text { avoidances, etc. }\end{array}$ & $\begin{array}{l}\text { Trading legal goods } \\
\text { and services. }\end{array}$ & $\begin{array}{l}\text { Business activities } \\
\text { based on the "do it } \\
\text { yourself" principle } \\
\text { and jobs performed } \\
\text { with the help from } \\
\text { friends. }\end{array}$ \\
\hline
\end{tabular}

Source: Schneider \& Buehn, 2018

Societies characterized by a high shadow economy rate, justify the lack of power to repress it by stating that people are by nature prone to performing shadow economy activities (Tomaš, 2010, p. 45). The shadow economy is much less present in democratically organized societies, while its presence grows with an irrational use of budgetary resources and inadequate supply of goods and services. The shadow economy is usually observed through its negative sides because it primarily implies the lack of public incomes that would be present in the normal realization of economic activities. According to Tomaš (2010, p. 46), the wide range of the shadow economy points out to the lack of elementary functions of the modern country, meaningless of the existence of state institutions, as well as to the disturbances of the value system that crosses the boarders of the achieved civilizational level of the modern society. Hence, the presence of the shadow economy is more related to poor state efficacy on the matter of solving social and economic issues than to the unawareness of citizens. However, its occurrence can bring certain advantages to a certain society. According to Uzunoglu, Yuruk, \& Atakisi (2002), the shadow economy can contribute to an increase in competitiveness and dynamics of the economy, affect the employment growth and ensure economic resources, make impact on the multiplication effect, etc.

The shadow economy has a negative impact on the economic efficacy for several reasons: it increases transactional costs; consumers are getting products of poor quality or without guarantee; consumers and the environment are exposed to an increased risk because companies in the shadow economy are avoiding safety and ecological standards; it has a negative influence on poverty and inequality because employees in the shadow economy often do not have social and health insurance; the state does not get all the tax and permit incomes that would exist in legal conditions which can further cause a series of negative consequences. The last reason is especially important for states facing fiscal consolidation challenges - like the Republic of Serbia (Golubović \& Džunić, 2015).

The shadow economy indirectly affects the growth of tax burden of all entities doing business in the formal sector, the decrease of the standard of living, the negative perception about the state authorities, the degradation of the legal order, as well as the public's lack of trust in state institutions. It leads to the occurrence of unreliable statistical data relevant for 
establishing economic characteristics and social distribution which then makes us question the decisions and effects of the realization of economic policies. Likewise, it has a negative impact on market competitiveness because market participants doing business in the shadow economy do not pay taxes or do so in a significantly lower range than legal companies and in that way gain disloyal competitive advantage on the market. However, companies from the shadow zone do not have access to developmental programs or loans and the support of the official institutions, so these companies can become inefficient and can contribute to a slower development and the application of modern technologies and knowledge.

GDP per capita and theshadow economy are co-dependent, i.e. when GDP per capita decreases, the shadow economy increases. In essence, this means that if GDP is decreasing, the pressure on the shadow economy is increasing because economic entities of reduced business possibilities in the formal sector will try to compensate losses by being engaged in the shadow zone. For these reasons, and in the direction of formalizing theshadow economy, it is important to maintain macroeconomic stability and create conditions for economic growth.

The survival of the shadow economy owes plenty to corrupt governmental structures, so the participants in theshadow economy are often financiers from corrupt social layers. The phenomena of corruption and tax evasion are constantly present and directly determine the structure and dynamics of the shadow economy in every country (Dreher \& Schneider, 2006; Buehn \& Schneider, 2012). According to Mulgan (2012, p. 25), the negative connotation and harmfulness of corruption, which is often reflected in the form of nepotism, cronyism and bribery, comes from an apparent abuse of power.

Corruption is Serbia is very much present and is often defined as one of the most important problems in the country. On the scale from zero to one hundred, zero signifying high corruption rate and one hundred signifying no corruption at all, in 2018 on the matter of corruption in the public sector, Serbia scored 39 points and took the 87th place out of 180 analysed countries, whereas countries with a higher ranking have a higher level of corruption (Transparency International, 2017). A research carried out on the sample of 343 respondents proved that corruption in Serbia is very much present. Namely, $35.3 \%$ of all respondents stated that their friends, family or they personally had at least once in their lives bribed somebody (Đekić, Čukanović-Karavidić, \& Filipović, 2017). Also, research in our country show that corruption stands out as one of the biggest problems of citizens, just behind poverty, unemployment and crime, as well as that it is present within the system, so it seems the citizens have accepted corruption and that kind of behaviour as socially acceptable (Tanjević, 2016).

\section{Methods of assessing the shadow economy}

Scientific research activities should be focused on developing internationally comparable methodology of assessing theshadow economy in order to avoid possible misunderstandings and poor estimates of the shadow economy, corruption and fiscal frauds (Zaman \& Goschin, 2016). The shadow economy can be assessed, i.e. its participation in GDP can be estimated regardless of the fact it appears to be something beyond the state control reach and the fact it is not covered by the official statistics. According to Andrei (2011), the share of theshadow economy is GDP is an indicator determining the size, intensity and negative impact of the shadow economy. Quantifying is possible thanks to the 
traces the shadow economy leaves behind, hence the system of forensic revision enables more precise assessments. Forensic accounting should overlook and assess such actions, provide independent and unbiased opinion and give evidence for an illegal action. Previously explained forensic accounting is of curative type, but there is also one that is preventive and whose task is to prevent the occurrence of illegal economic and financial actions (Đekić, Filipović, \& Gavrilović, 2016).

Most commonly used methods for quantifying the shadow economy are (Bešlić \& Bešlić, 2009):

1. Discrepancy between expenditures and incomes - An individual or an organized privileged group can avoid reporting their incomes or they can report them but only partially. However, the largest portion of incomes is, at one point, expressed as an expense when making new investments. There are numerous reasons for not reporting one's incomes, hence the estimates of GDP are considered biased. There are many reasons for the existence of the discrepancy between the initial estimate of reported incomes and final incomes. This hypothesis has been proven in practice.

2. Labour market method - The size of the shadow economy is indicated by low participation rates compared to the previous period or to rates measured in different countries where the phenomenon of the shadow economy is not that much present. The discrepancy between the official and the usual rate determines the size of the labour force participating in the shadoweconomy. If we add incomes to this number, we get an estimate of the size of the shadow-economic activities in an absolute amount of money. Surveys about the use of work hours are used as a method of calculating the shadow economy. They point out to how certain categories (e.g. employees on side jobs, retirees) use their available time which indirectly tells us what categories are involved in the shadow economy activities. When a research is carried out on a representative sample, the results can be extrapolated and in that way we can get the quantity of the shadow economy for the economy as a whole.

3. Tax revision method - it refers to the active engagement of tax structures in identifying shadow incomes. It is achieved via tax revision that emphasizes information about, for example, what groups and professions most commonly do not report or partially report their incomes. Various methods are used when choosing the population sample. Random sample is the most common one, but discriminatory procedures are sometimes used in order to develop an algorithm for selecting tax payers most suitable for the calculation.

4. Monetary method - it is based on the assumption that individuals hiding their activities also change the pattern of money use. One of the basic methods is based on the assumption that cash transactions are less visible and more difficult to be noticed than non-cash transactions. Therefore, participants in theshadow economy prefer cash, and changes in structure and the amount of cash are indicators that can help in estimating theshadow economy. A more complex method implies the analysis of the relation between cash and sight deposits in banks.

How much shadow economy is present is estimated based on the following three methods: 
1. MIMIC method is based on modelling and it covers the widest range of economic anomalies since it covers all the institutional sectors and all forms of the shadow economy (profit tax, property tax, fees, etc.);

2. Household Tax Compliance Method-covers those forms of the shadow economy which can be estimated based on the data about the incomes and consumption at the level of households;

3. Surveys about how companies and entrepreneurs do business.

Estimates obtained by the MIMIC method give a bit higher level of the shadow economy than those obtained by the direct method since MIMIC covers the shadow economy of unregistered business entities.

\section{The range of the shadow economy in selected countries and in Serbia}

The shadow economy is a highly complex research field demanding comparisons at the national level which can impact the decisions about the domestic and international business environment, estimates about state governance, private and public sector, direct foreign investments, etc. (Buehn, Lessmann, \& Markwardt, 2013; Charles, 2011). In the aim of reviewing the problems and representation of the shadow economy in Serbia, it is necessary to consider the level of this phenomenon in other countries. Surely, when analysing movements of the shadow economy through time intervals and comparing different countries, it is necessary to consider the method that was used to assess the shadow economy in a certain country in the given time frame.

The following Graph shows the share of the shadow economy in GDP at different regions and observed within three time intervals covering the period starting from 1999, ending with 2015. The authors Medina \& Schneider (2017) analysed 158 countries and established that, for the period from 1996 to 2015, the average height of the shadow economy was $32.5 \%$ of the GDP, whereas in 1991 it was $34.82 \%$ and in 2014 it fell down to $30.66 \%$ of the GDP.

Graph 1: The shadow economy by regions - average amounts as \% in the GDP

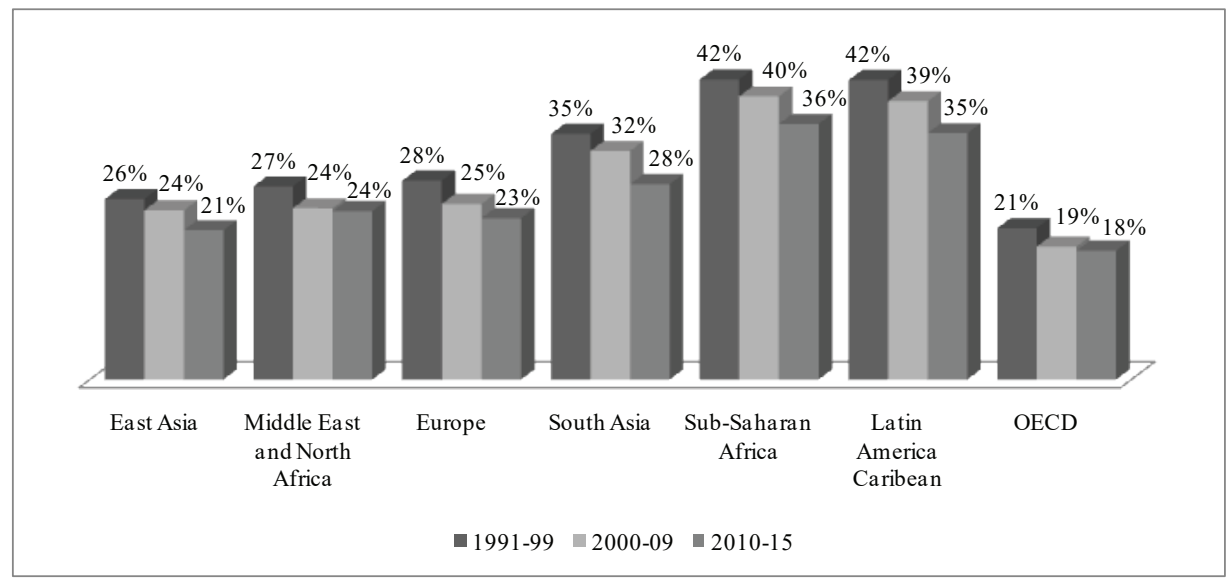

Source: Medina \& Schneider, 2017 
From the previous Graph, we can see that the lowest share of the shadow economy in GDP is present in OECD countries, then in the European countries, countries of Eastern Asia, Middle East countries and North Africa, and the highest share is in the sub-Saharan Africa and Latin America.

According to Schneider, Raczkowski, \& Mróz (2015), the average level of the shadow economy in the European Union was $22.6 \%$ of GDP in 2003 and it decreased to $18.6 \%$ in 2014. According to one research that included 158 countries and the period between 1991 and 2015, the average share of the shadow economy in GDP was 31.9\% (Medina \& Schneider, 2018, p. 23). The following Graph shows the share of the shadow economy in GDP of South and East European countries for 2015.

Graph 2: The shadow economy in the countries of South and East Europe for the year 2015 (in \% of the GDP)

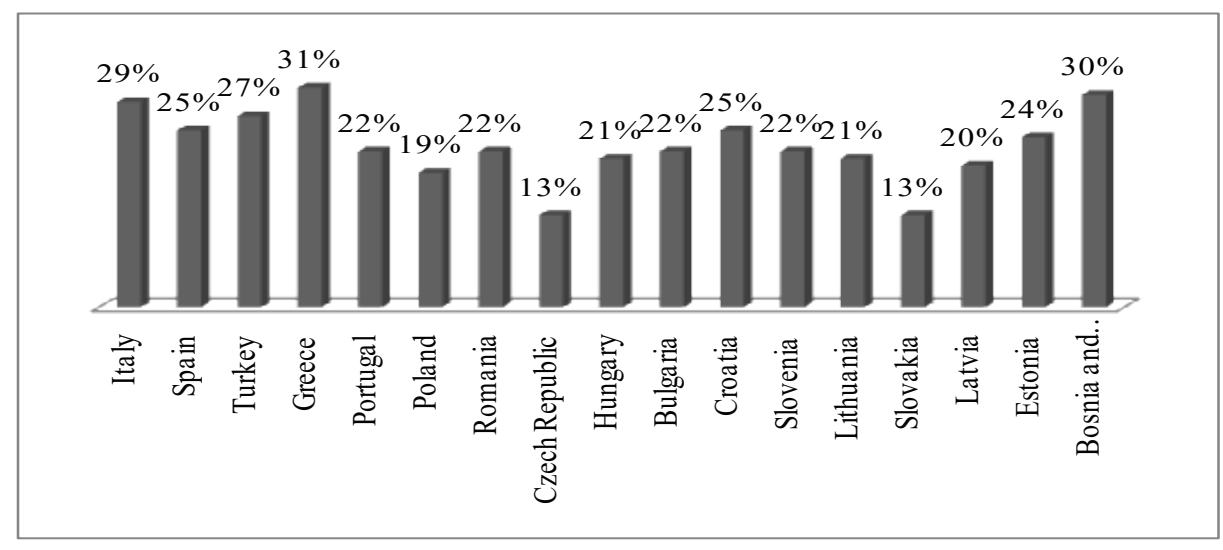

Source: Krstić \& Radulović, 2018

It must be mentioned that the institutionalization of the shadow economy in developed countries is much higher than in the East European countries which means that the share of the shadow economy in GDP of those countries is at a much lower level - a consequence of a long and difficult struggle of the developing countries with the shadow economy.

Talking about our country, we can say that the shadow economy got more prominence in the war and post-war period because illegal activities going on during the war continued to exist afterwards. The transition period in our country is characterized by speculation in the purchase of social housing and in the process of privatization of state and social enterprises, often followed by organized crime. The country that was in the economic crisis was not ready enough to direct economic flows and fully control the market in the process of transforming the economic system. When dealing with organized crime, in addition to the presence of corruption, smuggling and illicit trafficking, there are various forms of falsification, "money laundering", abuse of authority and official position, especially in Serbia. Nevertheless, the most significant form affecting the entire population of one country is precisely the tax evasion, or the avoidance of tax payments or the conscious violation of regulations by which every country regulates their tax system. Tanjević, Galjak, \& Opačić (2012) argue that financial misbehaviour in Serbia is most often manifested in the form of avoidance of 
customs duties, various types of taxes, excise duties and services, as well as other taxes and fiscal obligations that represent an important source of public revenue. Likewise, according to Raonić \& Vasić (2014), phantom companies in Serbia serve the purpose of VAT evasion, which, due to the concept of credit reimbursement, enables a specific type of abuse.

In Serbia, the shadow economy is not only a consequence, but also the cause of the reduced GDP. According to Schneider (2016), the shadow economy in Serbia has an exceptionally high level when observed in comparison with GDP. The same source states that when using different methodological approaches for 2010, the following results were obtained: the estimated value of the shadow economy according to the MIMIC method was $30.1 \%$ of GDP; According to HTC (Household Tax Compliance) method this value was $23.6 \%$. Using the survey method, it was concluded that the value of the shadow economy in Serbia in 2012 was $21.2 \%$. According to Krstic \& Schneider (2015, p. 49), by using the MIMIC method, the value of the shadow economy was as high as $33.2 \%$ in the previous decade or in 2001 . The following table shows the extent of the estimated shadow economy in Serbia, shown in \% of GDP, measured by various methods.

Table 2: The range of shadow economy in Serbia for the period between 2010 and 2017 (\% of GDP) - different methods

\begin{tabular}{|l|c|c|}
\hline Estimation methods & Year & Shadow economy in \% of GDP \\
\hline HTC method & 2010. & $23,6 \%$ \\
\hline MIMIC method & 2010. & $30,1 \%$ \\
\hline Direct survey method & 2012. & $21,2 \%$ \\
\hline Direct survey method & 2017. & $15,4 \%$ \\
\hline
\end{tabular}

Source: Krstić \& Radulović, 2018

According to estimates by the 2012 Survey Method, the shadow economy in enterprises and at entrepreneurs was about $21 \%$ of GDP. These data were obtained by observing the two most important forms of the shadow economy - product turnover and partially or completely illegal work (Krstić, et al., 2013, p. 4). Systematized data from the above-mentioned survey showed that the shadow economy in Serbia is $15 \%$ higher than the average of Central and Eastern European countries, which suggests that the tax gap in Serbia is so much higher than in the mentioned countries.

Using the 2012 survey method in 2017 on the sample of economic entities that participated in the aforementioned earlier research, it can be concluded that the volume of the shadow economy in the area of turnover and earnings has been reduced. Also, according to Krstić \& Radulović (2018), salaries of employees in the shadow economy accounted for as much as $61.3 \%$, while the rest comes from unreported profits.

Based on the data presented in the table, it can be concluded that the estimated amount of the shadow economy on the basis of the Survey is the lowest: companies achieve shadow economy in other tax forms, such as income tax, property tax, fees, etc. However, there is a part of the shadow economy achieved outside of the company (handymen, private classes, etc.). By comparing these results with estimates obtained by the MIMIC method, it can be said that $2 / 3$ of the total shadow economy is scooped in companies and at entrepreneurs' in the form of an illegal turnover and employee payments without paying all tax liabilities. 
According to Krstić, et al. (2013), the reduction of the shadow economy in the medium term (up to three years) could increase public revenues by about $0.8-1.1 \%$ of GDP, while in the long term (from five to seven years) it may be expected to increase public revenues to around $2 \%$ of GDP. Such effects would be possible if adequate measures to reduce the shadow economy were being implemented through an organized, continuous and systematic approach. The taxation of the shadow economy should contribute to the reduction of the fiscal deficit as well as to offset the fall in tax revenues due to the expected restitution of the economy towards less taxable activities - exports and investments.

In January 2018, the Minister of Serbia announced the reform of the tax administration, which is one of the most important steps in the recent battle against the shadow economy. The plan envisages the establishment of thirty-five offices across the country, investment in a new IT platform, and the discretion of tax inspectors to waive the collection of corporate tax, provided that the economic subject invests this money into production (Culkin\& Simmons, 2018, p. 21).

\section{Conclusion}

The shadow economy can be explained and defined in various ways, though the essence of the term remains the same. Irrespective of the preferred definition, it refers to all economic flows, actions and related income that are not subject to taxation, as well as to any valid regulation. More precisely, the extensive definition of the term shadow economy includes all illegal activities, ranging from unrecorded revenue from goods and services turnover, through financial transactions and barter arrangements, to business activities in a self-directed manner. The shadow economy implies the production and trafficking of illegal or legal products and services that cannot be detected by official methods of GDP estimation. On the other hand, it can be said that the shadow economy also includes market-based production of licensed products and services that are clearly concealed and excluded from the range of control bodies of public administration. In other words, the shadow economy is a market-verified part of the legal economy that takes place in an illegal manner. The spread of shadow economy also encourages the spread of the black market and the black economy as a forbidden form of business activity. The development of the shadow economy is favoured by insufficient power or insufficient interest in the legislative and government structures to fight against the shadoweconomy, its manifestations, and all the negative economic misconduct.

Shadow economy is a significant obstacle to the development of strong private sector enterprises and an efficient market system. The shadow economy faced by the Serbian economy is one of the biggest challenges and its consequences are visible in the area of tax evasion, market distortion, unfair competition and inefficient allocation of resources. Although the shadow economy is still important for many individuals, the negative consequences for the employed, the economy and society as a whole far outweigh all its benefits. The share of shadow economy in Serbia's GDP, measured by various methods of assessment, is at a high level, and new reforms and measures should influence the reduction of the level of this negative phenomenon. Serbia has prepared a set of measures and an action plan to combat shadow economy, and the most important place in this struggle against the shadow economy belongs to the tax system of the country. The main goal in reducing the shadow economy and the tax gap in Serbia is their reduction to the level of Central and Eastern European 
countriesin mid-term, while in the long term this goal could be to approach the levels of Western Europe. This is important due to the increase in tax revenues, the development of a market-driven economy and European integrations.

\section{References}

Andrei, T. (2011). Relations de causalité entre l'economie souterraine et les variables macroéconomiques:. application sur la Roumanie, Revista Română de Statistică, nr. 3, 2011, $86-100$.

Bešlić, D., \& Bešlić, I. (2009). Siva ekonomija u Srbiji. Škola biznisa 2, 35-41.

Buehn, A., \& Schneider, F. (2012). Corruption and the shadow economy: like oil and vinegar, like water and fire? International Tax and public Finance, 19(1), 172194.

Buehn, A., Lessmann, C., \& Markwardt, G. (2013). Decentralization and the shadow economy: Oates meets Allingham-Sandmo. Applied Economics, 45(18), 25672578 .

Charles, S. (2011). Institutional Quality and Economic Growth in Latin America. Global Economy Journal, 10(4). doi:10.2202/1524-5861.1710

Culkin, N., \& Simmons, R. (2018). Study of the challenges that hinder MSME development in the Republic of Serbia. London : British Council.

Dreher, A., \& Schneider, F. (2006). Corruption and the Shadow Economy: an Empirical Analysis. CESifo Working Papers Series 1613, CESifo Group Munich.

Đekić, M., Čukanović-Karavidić, M., \& Filipović, P. (2017). Korupcija kao oblik finansijske prevare i njena zastupljenost u Srbiji. Revizor, Vol. 21, No. 81, 101113.

Đekić, M., Filipović, P., \& Gavrilović, M. (2016). Forenzičko računovodstvo i finansijske prevare u svetu. Ekonomija: teorija i praksa, 9(4), 71-86.

Golubović, N., \& Džunić, M. (2015). Social capital as a determinant of the shadow economy in the Republic of Serbia. Ekonomski horizonti, 17(3), 173-187.

Krstic, G., \& Schneider, F. (2015). Formalizing the Shadow Economy in Serbia. London: Foundation for the Advancement of Economics for the USAID Business Enabling Project. doi:10.1007/978-3-319-13437-6

Krstić, G., \& Radulović, B. (2018). Siva ekonomija u Srbiji 2017: Procena obima, karakteristike učesnika $i$ determinante. Beograd: Nacionalna alijansa za lokalni ekonomski razvoj.

Krstić, G., Schneider, F., Arandarenko, M., Arsić, M., Radulović, B., Ranđelović, S., \& Janković, I. (2013). Siva ekonomija u Srbiji: Novi nalazi i preporuke za reforme (rezime studije). Beograd: Fond za razvoj ekonomske nauke - FREN.

Medina, L., \& Schneider, F. (2017). Shadow Economies Around the World: New Results for 158 Countries Over 1996-2015, CESifo Working Paper, No. 6430. Center for Economic Studies and Ifo Institute (CESifo), Munich. 
Medina, L., \& Schneider, F. (2018). Shadow economies around the world: what did we learn over the last 20 years? Retrieved May 25, 2019, from http://wp.flgr.bg/ wp-content/uploads/2018/06/imf_shadow_2017.pdf

Mulgan, R. (2012). Corruption: Expanding the Focus. Canberra: ANU Press.

Novaković, N. G. (2015). Shadow economy, crisis and transition in Serbia. Zbornik radova Filozofskog fakulteta u Prištini, (45-2), 259-279.

OECD. (2002). Measuring the Non-Observed Economy - A Handbook. Paris.

Raonić, I., \& Vasić, Z. (2014). VAT fraud in Serbia and phenomenon of shell (phantom) companies. Ekonomika, 60(2), 95-106.

Schneider, F. (2006). Shadow Economies and Corruption all over the World: What do we really know?, Working Paper No. 0617. Linz: Johannes Kepler University of Linz, Department of Economics. Retrived April 30, 2019, from https:/www. econstor.eu/handle/10419/73309

Schneider, F. (2011). The Shadow Economy and Shadow Economy Labor Force: What Do We (Not) Know, IZA Discussion Papers No. 5769. Bonn: Institute for the Study of Labor. Retrieved Jun 15, 2019 from http://nbn-resolving.de/ urn:nbn:de:101:1-20110621286

Schneider, F. (2016). Comment on Feige's Paper "Reflections on the Meaning and Measurement of Unobserved Economies: What do we really know about the 'Shadow Economy'? CESifo Working Paper, No. 5818. Munich: Center for Economic Studies and Ifo Institute (CESifo).

Schneider, F., \& Buehn, A. (2018). Shadow Economy: Estimation Methods, Problems, Results and Open questions. Open Economics, 1, 1-29. doi:10.1515/ openec-2017-0001

Schneider, F., Raczkowski, K., \& Mróz, B. (2015). Shadow economy and tax evasion in the EU. Journal of Money Laundering Control, 18(1), 34-51.

Smith, P. (1994). Assessing the size of the underground economy: the Canadian statistical perspectives. Canadian Economic Observer, Catalogue no. 11-010, $16-33$.

Tanjević, N. (2016). Uloga i značaj etičkih standarda zaposlenih u javnoj upravi i smanjenje korupcije. Trendovi u poslovanju, Vol. 4, No. 7, 79-89.

Tanjević, N., Galjak, I., \& Opačić, A. (2012). Problem of the field 'underground economy' in Serbia. Ekonomika, 58(1), 70-79.

Tomaš, R. (2010). Crisis and Gray Economy in Bosnia and Herzegovina. Sarajevo: Friedrich-Ebert-Stiftung.

Transparency International. (2017). Corruption Perceptions Index 2018. Retrieved July 05, 2019, from https://www.transparency.org/cpi2018\#results

Uzunoglu, S., Yuruk, M., \& Atakisi, A. (2002). Underground Economy: It is an Economic Problem a Solution. Retrieved Jun 30, 2019, from http://www. noahsarchives.com/noahs_archives/undrgr_econ_prob_or_solution.pdf

Zaman, G., \& Goschin, Z. (2016). A new multidimensional ranking of shadow economy for EU countries. Romanian Journal of Economics, Vol. 43, 14-33. 